\title{
Interleukin 6 and AIDS-Associated Kaposi's Sarcoma: A Nested Case Control Study within the Multicenter AIDS Cohort Study
}

\author{
INÊS DOURADO, ${ }^{1,2}$ OTONIEL MARTÍNEZ-MAZA, ${ }^{1,3}$ TADAMITSU KISHIMOTO, ${ }^{4}$ \\ HIROMASA SUZUKI, ${ }^{5}$ and ROGER DETELS ${ }^{1}$
}

\begin{abstract}
Since the beginning of the AIDS epidemic, there has been considerable research on the etiology of Kaposi's sarcoma (KS) among HIV-infected individuals. A number of studies have confirmed that HIV or HIV-encoded products can interact with human cells to induce the production of cytokines, including interleukin 6 (IL-6). In vitro observations have indicated that AIDS-KS cells can produce significant levels of IL-6 and also respond to this cytokine. Preliminary data suggested that IL-6 may be elevated among HIV-infected individuals that subsequently develop AIDS-KS. The objective of this study was to determine if elevated levels of IL6 are associated with an increased incidence of AIDS-KS compared to other AIDS-defining illnesses such as opportunistic infections (OIs). Serum IL-6 levels were determined by ELISA in frozen sera collected from participants in the Multicenter AIDS Cohort Study (MACS) at 6 months prior to AIDS diagnosis, in 73 cases (AIDS-KS), and 152 controls (OI). Elevated IL-6 levels were more prevalent among men with AIDS-OI than those with AIDS-KS: crude odds ratio (OR), 0.4 (95\% CI, 0.2-0.9). Models of multivariate logistic regression were used to study potential confounders. Sexual behavior variables did not seem to confound the association between IL-6 and AIDS-KS. The higher prevalence of IL-6 among controls could be explained by the association of higher levels of IL-6 with lower levels of CD4 T cell number. IL-6 may be a marker of severe immune dysfunction among HIV-infected individuals.
\end{abstract}

\section{INTRODUCTION}

$\mathbf{P}$ RIOR TO THE AIDS EPIDEMIC, Kaposi's sarcoma (KS) was a rare tumor in North America and Europe. The disease was mostly reported in elderly men, 50 years or more of age, of eastern European and Mediterranean origin such as Italians and Jews of Polish and Russian ancestry. ${ }^{1-5}$ In 1979, a number of cases of the aggressive, disseminated, fatal form of $\mathrm{KS}$ were recognized among young to middle-aged homosexual men. It soon became clear that $\mathrm{KS}$ is one of the most frequent clinical manifestations of $\mathrm{HIV}$ infection, and that $\mathrm{KS}$ is the most com- mon AIDS-associated cancer. ${ }^{6}$ It occurs much more frequently among homosexual and bisexual HIV-infected men than it does in other risk groups. Kaposi's sarcoma may be the direct manifestation of the HIV-induced impairment of the immune system, or may be caused by some other process, pathogenic organisms, or a combination of factors seen among HIV-infected individuals.

Some time ago, Ensoli et al. ${ }^{7}$ proposed a model to explain the mechanisms involved in the association between KS and HIV infection, based on results from in vitro and in vivo studies with transgenic mice. According to this model, in HIV-in-

\footnotetext{
${ }^{1}$ Los Angeles Center of the Multicenter AIDS Cohort Study, Department of Epidemiology, UCLA School of Public Health, Los Angeles, California 90095 .

${ }^{2}$ Instituto de Saúde Coletiva, Federal University of Bahia, Brazil.

${ }^{3}$ Department of Microbiology and Immunology and Department of Obstetrics and Gynecology, UCLA School of Medicine, Los Angeles, California 90095 .

${ }^{4}$ Department of Medicine III, Osaka University Medical School, Osaka, Japan.

${ }^{5}$ Research Laboratories, Fujirebio, Inc., Tokyo, Japan.
} 
fected individuals, the combination of factors released from activated lymphocytes and factors released from infected $\mathrm{T}$ cells, e.g., the HIV Tat protein, induce the proliferation of specific types of normal cells (endothelial, smooth muscle cells, and/or fibroblasts) that later can be transformed into spindle-shaped cells. These KS precursor cells can produce several cytokines including interleukin 6 (IL-6), IL-1 $\beta$, and tumor necrosis factor (TNF) that may induce their own growth (autocrine pathway). Also, proliferation of KS spindle cells might be enhanced by cytokines produced by other cells (paracrine pathway). The interaction between normal and spindle cells undergoing uncontrolled proliferation and growth may lead to the development of a KS lesion. As with other lesions, if secondary genetic changes take place, the KS lesion can be transformed into a tumor and/or malignancy.

While HIV-encoded products can promote the growth of KS cells, this does not explain the higher risk of KS among homosexual and bisexual men. ${ }^{8}$ This observation raised important questions regarding the etiology of AIDS-associated KS (AIDS$\mathrm{KS}$ ): possibly, a cofactor that is more prevalent among homosexuals than heterosexuals with HIV infection was involved in the induction of KS. The lifestyle of these individuals, who have frequent episodes of sexually transmitted diseases, may predispose them to chronic antigenic stimulation differentially from other risk groups. The combination of HIV infection and chronic antigenic stimulation may contribute to the development of KS via the production of "inflammatory" cytokines (IL1, TNF, IL-6) released from activated immune cells. These cytokines have potent cell growth-promoting activity and have been found in increased levels in the sera or in the supernatant of blood cells from HIV-1-infected individuals. ${ }^{9-11}$

It also is possible that homosexual and bisexual men may be at greater risk for the acquisition of a unique, sexually transmitted agent that can induce KS. ${ }^{12-15}$ Presumably, such an agent would be transmitted more efficiently sexually than perinatally, through needle sharing or through blood products. The agent may have been endemic in the homosexual population before HIV became prevalent, and the immunodeficiency that accompanies HIV infection allowed the agent to express itself. Work performed by Moore et al. ${ }^{16-18}$ suggests that a previously unrecognized herpesvirus is associated with, and may contribute to, the pathogenesis of AIDS-associated KS: DNA sequences for a previously uncharacterized human herpes-type virus were detected in KS lesions. Sequences characteristic of this new KSassociated herpesvirus (KSHV or HHV-8) are present in most KS lesions, including those from people who are not HIV positive; however, KS-derived cell lines with spindle cell morphology generally do not contain KSHV, and various B cell lines have been seen to be KSHV positive. ${ }^{17-22}$ While the association of KSHV with KS lesions has been established clearly, the role of this new virus in the pathogenesis of AIDS-KS is not clear. Direct infection of cells involved in KS lesions may be involved in the establishment of these cancers. However, the means by which KSHV infection contributes to KS have not been determined. Perhaps, KSHV enhances the development or growth of KS lesions by enhancing cytokine production, either by the primary tumor cells (autocrine), or by infiltrating immune system cells (paracrine). The interaction of KSHV with endothelial cells, B lymphocytes, or monocytes/macrophages might lead to the production of cytokines, including cellular IL-
6 (cIL-6), known to enhance KS cell growth, although this remains to be determined experimentally. Interestingly, reports indicate that the KSHV/HHV-8 genome encodes a viral version of human IL-6 (vIL-6). ${ }^{23,24}$ The biological properties of vIL-6, and the effects of this molecule on KS cell growth, have not been defined.

Initial interest in examining the role of IL-6 in AIDS-KS was stimulated by in vitro observations that AIDS-KS cell lines can produce various cytokines and growth factors. ${ }^{25-34}$ These studies demonstrated enhanced growth of AIDS-KS cells when they were cultured with conditioned media from $T$ cells infected with human retroviruses, suggesting that a growth factor for AIDSKS cells was present. Interleukin 6 was considered to be a potential growth factor for AIDS-KS cells because its characteristics are similar to those of the growth factor isolated from the T cell supernatant. Subsequent work demonstrated that various AIDS-KS cell lines can produce significant amounts of IL-6 and can respond to IL- $6 .^{26,27,32,33}$ It is not known whether the IL-6 produced by these KS cells is of cellular or viral origin. Furthermore, exposure of AIDS-KS cells to IL-6 antisense oligodeoxynucleotides, which diminish the production of endogenous IL-6, resulted in decreased KS cell proliferation. ${ }^{27,28}$ Other cytokines, including TNF, IL- $1 \beta$, oncostatin $\mathrm{M}$, and basic fibroblast growth factor (bFGF), as well as the HIV Tat protein, also seem to be able to induce AIDS-KS cell proliferation and IL- 6 production by KS cells. ${ }^{29,30}$ These results suggested that various factors, particularly oncostatin $M$, can independently, or together with IL-6, promote the proliferation and/or growth of spindle-shaped KS cells. ${ }^{28,30,31}$

Despite the association of IL-6 with the growth of AIDS-KS cells in in vitro studies, it had not been determined if elevated serum IL-6 levels could predict the development of KS among HIV-infected individuals. We, therefore, designed a nested case control study to investigate if elevated levels of serum IL- 6 are associated with an increased incidence of AIDS-KS compared to other AIDS-defining illnesses such as opportunistic infections (OI).

\section{MATERIALS AND METHODS}

\section{Study population}

The study used a nested case control design to estimate the effect of serum IL-6 level on the risk of AIDS-KS among HIVinfected men. An important feature of the nested case control design is that cases and controls come from the same source population. In addition, the exposure was ascertained prior to knowledge of outcome. These features reduce the potential for selection and ascertainment bias. It is also a more cost-efficient design than a design using the entire cohort, since we need to test only the case group and a sample of controls for IL-6.

The Multicenter AIDS Cohort Study (MACS) is one of the largest ongoing cohorts of homosexual and bisexual men, 18 to 68 years old, who did not have AIDS at the time of entry into the study. This closed cohort was initiated in 1984 and included men from four different cities in the United States: Los Angeles, Chicago, Baltimore, and Pittsburgh. A total of 4954 men was recruited and agreed to participate voluntarily in the study. The Los Angeles (LA) Center (UCLA School of Public Health) 
recruited 1637 study participants $18-50$ years of age. The participants have been seen approximately every 6 months for completion of a questionnaire; physical examination; and collection of specimens for HIV antibody testing, CD4 T cell measurements, and storage in local and national repositories. Cases of AIDS have been defined by the 1987 Center for Disease Control (CDC) criteria. ${ }^{35}$ These cases are identified in the MACS cohort through ongoing surveillance. Their diagnoses are confirmed by medical records and/or death certificates. The complete description of the MACS is available elsewhere. ${ }^{36,37}$ For the present analysis, we used the LA Center data through 1992.

Kaposi's sarcoma cases are self-reported during the followup interviews. The control group is composed of men with other AIDS opportunistic infections. The following opportunistic infections were included in the control group: Pneumocystis carinii pneumonia (PCP), toxoplasmosis, cryptosporidiosis, isosporiasis, cytomegalovirus (CMV), candidiasis, mycobacterial infection, cryptococcal meningitis, herpes simplex infection, coccidioidomycosis, and salmonellosis. Both KS and OI are confirmed by medical records and/or death certificates or autopsy: $95.6 \%$ of the KS cases in the LA-MACS have been verified, by biopsy or clinically.

\section{Measurement of Interleukin 6}

Interleukin 6 was measured in the sera of study subjects at three time points: 6 months, 1 year, and 2 years before AIDS. Serum IL-6 level was determined by an enzyme-linked immunosorbent assay (ELISA) (Fujirebio, Tokyo, Japan) able to detect 4 pg of IL-6 per milliliter of serum.

\section{Analysis}

Frequency distributions were determined for each variable, including mean and standard deviations for continuous variables. The information on selected variables was taken for the same time point that IL- 6 was measured. Crude odds ratios and $95 \%$ confidence intervals for the association of IL-6, other selected variables, and AIDS-KS were calculated from $2 \times 2$ tables. ${ }^{38,39}$ Interleukin 6 was considered both as a continuous and as a categorical variable. An IL-6 level greater than $4 \mathrm{pg} / \mathrm{ml}$ was the cutoff point in determining when to consider a study subject as exposed. We choose to use $4 \mathrm{pg} / \mathrm{ml}$ because it was the lowest consistent level of IL-6 detected using the Fujirebio ELISA. Age was considered as a categorical variable (18-34 and 35-50 years). CD4 $\mathrm{T}$ cell number was considered both as a continuous and as a categorical variable $\left(<200\right.$ cells $/ \mathrm{mm}^{3}$ and $\geq 200$ cells $/ \mathrm{mm}^{3}$ ). The selected sexual behavior information was determined from reported sexual activities within the previous 6 months. Sexually transmitted disease (STD) status (syphilis and gonorrhea) in the previous 6 months was categorized as yes or no. The reported number of sexual partners was dichotomized at $0-20$ and greater than 20 as used by Archibald et al. ${ }^{14}$ Each of the other sexual behavior variables in this analysis was categorized as experiencing this behavior with "no partners and/or a single partner" (reference category) or with "multiple partners." $\beta_{2}$-Microglobulin $\left(\beta_{2} \mathrm{M}\right)$ and neopterin were dichotomized as "low" or below the medium value versus "high" or above the median value for both. The median value for $\beta_{2} \mathrm{M}$ was $3.01 \mathrm{ng} /$ liter and for neopterin was $17 \mathrm{nmol} / \mathrm{liter}$. Linear regression analysis was used to verify the correlation of
IL-6 with CD4 cell number, $\beta_{2} \mathrm{M}$, and neopterin. A multiple logistic regression model was used to obtain the adjusted estimates of the IL-6-AIDS-KS disease odds ratio. The statistical package $\mathrm{SAS}^{40}$ was used to perform the different steps of the analysis.

\section{RESULTS}

Within the entire LA-MACS cohort, the distribution of first AIDS diagnosis for selected diseases through December 1992 was as follows: 117 cases of KS (28.7\%), 163 cases of PCP (40\%), 27 cases of CMV (6.6\%), and 101 cases of other opportunistic infections (24.8\%). A large percentage of individuals experiencing an AIDS outcome were tested at each time point. Not everyone was tested at each visit because there was no serum available at every time point for all men for two reasons: either the participant had not come for that follow-up visit, or there was only one vial of serum left for the subject for that visit. Of the KS cases diagnosed through December 1992, we tested 73 subjects $(62.4 \%)$. Among the OI controls we tested the following percentages: PCP, 49.1\% (80 of 163); CMV, $48.1 \%$ (13 of 27); and other OI, $58.4 \%$ (59 of 101 ).

There were virtually no detectable levels of serum IL-6 at 2 years or 1 year prior to AIDS. In contrast, there were detectable levels of serum IL- 6 seen at 6 months pre-AIDS. The 6 months prior to AIDS is the time point that we, therefore, chose to analyze in terms of the association of IL- 6 as a predictor of AIDSKS. This analysis includes 73 cases (AIDS-KS) and 152 controls (AIDS-OI combined).

Cases and controls were similar with respect to race, ethnicity, and education at baseline. The case group was slightly older than the control group: $58.6 \%$ of cases and $62.7 \%$ of controls were between 15 and 34 years of age and $41.4 \%$ of cases and $37.3 \%$ of controls were between 34 and 48 years of age. The mean age was 33.2 years for the cases and 32.7 years for the controls at study entry $(p=0.46, t$ test for difference in means).

Elevated serum IL-6 (>4 pg/ml) was more prevalent among the control group than among the cases (Table 1). The crude odds ratio (OR) and 95\% confidence intervals (CI) for the association between IL- 6 and AIDS-KS at 6 months prior to AIDS was $0.4(0.2-0.9)$. This OR is below the null value, which indicates a possible inverse association of IL-6 and AIDS-KS,

Table 1. Unaduusted Odds Ratios And 95\% Confidence INTERVALS FOR THE AsSOCIATION OF SERUM IL-6 AT 6 MONTHS PRIOR TO AIDS-KS AND OI

\begin{tabular}{lcccc}
\hline Risk factor & $\begin{array}{c}A I D S-K S \\
(\mathrm{~N})\end{array}$ & $\begin{array}{c}\text { OI } \\
(\mathrm{N})\end{array}$ & OR & $95 \% \mathrm{CI}$ \\
\hline IL-6 (2 levels) & & & & \\
$>4 \mathrm{pg} / \mathrm{ml}$ & 11 & 45 & 0.4 & $0.2-0.9$ \\
$0-4 \mathrm{pg} / \mathrm{ml}$ & 62 & 107 & & \\
IL-6 $(3 \mathrm{levels})$ & & & & \\
$0-4 \mathrm{pg} / \mathrm{ml}$ & 62 & 107 & 1.0 & \\
$4-10 \mathrm{pg} / \mathrm{ml}$ & 8 & 33 & 0.4 & $0.2-1.0$ \\
$>10 \mathrm{pg} / \mathrm{ml}$ & 3 & 12 & 0.4 & $0.1-1.7$ \\
\hline
\end{tabular}


i.e., IL-6 (serum levels $>4 \mathrm{pg} / \mathrm{ml}$ ) was more prevalent among men with opportunistic infections than among men with AIDS$\mathrm{KS}$. We also considered IL- 6 as an ordinal variable in order to investigate a potential dose-response relationship. However, we found no change in the odds ratios from one level to the other. The $95 \%$ confidence interval for the " $>10 \mathrm{pg} / \mathrm{ml}$ " stratum included the null value.

Also, we examined the association of IL- 6 with each individual group of diseases (Table 2). The odds ratios for AIDS$\mathrm{KS}$ compared with PCP, CMV, and other OI were consistently below the null value, suggesting that people with these other diseases had higher levels of serum IL- 6 than did those with AIDS-KS (Table 2). We examined the levels of IL- 6 for each individual disease in the control group, as well. The disease groups that had elevated serum IL-6 levels $(>4 \mathrm{pg} / \mathrm{ml})$ were as follows: PCP, CMV, and other OI, including cryptosporidiosis, Candida esophagitis, Mycobacterium avium infection, disseminated mycobacterial tuberculosis, cryptococcal infection, and wasting syndrome. These diseases did not show a specific pattern in the distribution of IL-6.

Table 3 summarizes the comparisons of the study groups for known risk factors for AIDS. The odds ratio for age was 1.4 (0.8-2.6), suggesting the possibility that younger MACS men are at greater risk of AIDS-KS as compared to AIDS-OI. The odds ratio, however, was not statistically significant. Higher levels of CD4 cell numbers were found to be associated with AIDS-KS [OR 1.8 (1.0-3.2)]. In fact, in our data, the mean CD4 cell number was higher for the cases than for the controls. The mean \pm standard deviation was $203 \pm 168$ for the cases and $158 \pm 142$ for controls ( $p=0.049$; test for difference). $\beta_{2}-\mathrm{Mi}$ croglobulin and neopterin appeared to be associated with a "protective" odds ratio for AIDS-KS, but the confidence intervals included the null value.

Oral-genital receptive intercourse and anal-insertive intercourse were the only two sexual behaviors that were significantly associated with the risk of AIDS-KS as compared to OI. Associations that were not statistically significant included hav-

Table 2. Unaduusted Odds Ratios and 95\% Confidence INTERVALS FOR THE ASSOCIATION OF IL-6 AT 6 MONTHS PRIOR TO AIDS AND AIDS-KS, Compared with DifFerent Control Diseases

\begin{tabular}{lcccc}
\hline$I L-6$ level $(\mathrm{pg} / \mathrm{ml})$ & $\begin{array}{c}A I D S-K S \\
(\mathrm{~N})\end{array}$ & $\begin{array}{c}P C P \\
(\mathrm{~N})\end{array}$ & OR & $95 \% \mathrm{CI}$ \\
\hline$>4$ & 11 & 21 & 0.5 & $0.2-1.1$ \\
$0-4$ & 62 & 59 & &
\end{tabular}

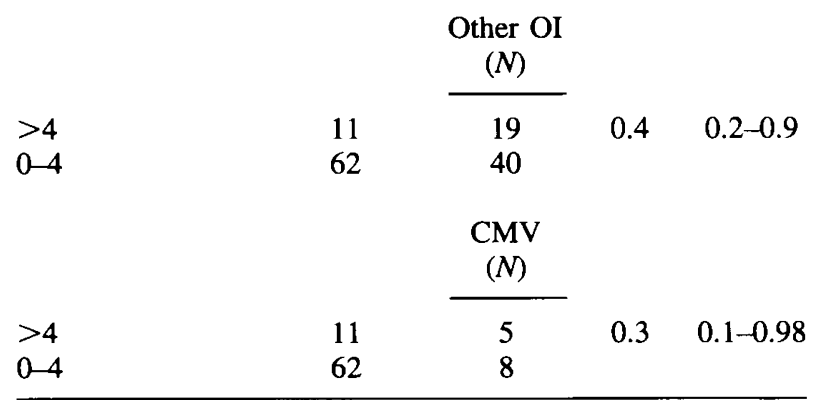

TABle 3. COMParison of POTENTIAL Risk Factors FOR AIDS-KS AND OI AT 6 MONTHS PRIOR TO AIDS: UNADJUSTED ODDS RATIOS AND 95\% CONFIDENCE INTERVALS

\begin{tabular}{|c|c|c|c|c|}
\hline Risk factor & $\begin{array}{c}A I D S-K S \\
(\mathrm{~N})\end{array}$ & $\begin{array}{l}O I \\
(\mathrm{~N})\end{array}$ & OR & $95 \% C I$ \\
\hline \multicolumn{5}{|l|}{ Age (years) } \\
\hline 15-34 & 31 & 52 & \multirow[t]{2}{*}{1.4} & \multirow[t]{2}{*}{$0.8-2.6$} \\
\hline $35-48$ & 42 & 100 & & \\
\hline \multicolumn{5}{|l|}{ CD4 cells $/ \mathrm{mm}^{3}$} \\
\hline$>200$ & 31 & 44 & \multirow[t]{2}{*}{1.8} & \multirow[t]{2}{*}{$1.0-3.2$} \\
\hline$\leq 200$ & 42 & 108 & & \\
\hline \multicolumn{5}{|l|}{$\beta_{2} \mathrm{M}$ (ng/liter) } \\
\hline$>3.01$ & 17 & 48 & \multirow[t]{2}{*}{0.7} & \multirow[t]{2}{*}{$0.3-1.6$} \\
\hline $1.3-3.01$ & 22 & 47 & & \\
\hline \multicolumn{5}{|c|}{ Neopterin (nmol/liter) } \\
\hline$>17$ & 19 & 50 & \multirow[t]{2}{*}{0.7} & \multirow[t]{2}{*}{$0.3-1.6$} \\
\hline $5-17$ & 25 & 45 & & \\
\hline \multicolumn{5}{|l|}{ Syphillis } \\
\hline Yes & 5 & 4 & \multirow[t]{2}{*}{2.7} & \multirow[t]{2}{*}{$0.7-9.8$} \\
\hline No & 67 & 143 & & \\
\hline \multicolumn{5}{|l|}{ Gonorrhea } \\
\hline Yes & 8 & 9 & \multirow[t]{2}{*}{1.9} & \multirow[t]{2}{*}{$0.7-5.1$} \\
\hline No & 64 & 138 & & \\
\hline \multicolumn{5}{|l|}{ Sexual Part ${ }^{\mathbf{a}}$} \\
\hline$>20$ & 6 & 6 & \multirow[t]{2}{*}{1.6} & \multirow[t]{2}{*}{$0.4-5.3$} \\
\hline $0-20$ & 44 & 71 & & \\
\hline \multicolumn{5}{|l|}{ Oral-genital Ins ${ }^{\mathrm{a}}$} \\
\hline Multiple & 38 & 60 & \multirow[t]{2}{*}{1.7} & \multirow[t]{2}{*}{$0.9-2.9$} \\
\hline Single/none & 35 & 92 & & \\
\hline \multicolumn{5}{|c|}{ Oral-genital $\mathrm{Rec}^{\mathrm{a}}$} \\
\hline Multiple & 41 & 61 & \multirow[t]{2}{*}{1.9} & \multirow[t]{2}{*}{$1.1-3.4$} \\
\hline None/single & 32 & 91 & & \\
\hline Anal sex $\operatorname{Ins}^{a}$ & & & & \\
\hline Multiple & 23 & 29 & 2.0 & $1.0-3.7$ \\
\hline None/single & 50 & 123 & & \\
\hline Anal sex $\operatorname{Rec}^{a}$ & & & & \\
\hline Multiple & 24 & 36 & 1.6 & $0.9-2.9$ \\
\hline None/single & 49 & 116 & & \\
\hline Rimming Ins ${ }^{a}$ & & & & \\
\hline Multiple & 9 & 11 & 1.8 & $0.7-4.5$ \\
\hline None/single & 64 & 141 & & \\
\hline Rimming Rec ${ }^{a}$ & & & & \\
\hline Multiple & 11 & 13 & 1.9 & $0.8-4.4$ \\
\hline None/single & 62 & 139 & & \\
\hline
\end{tabular}

a Risk activities reported at 6 months prior to this visit: Part, Number of partners; Ins, insertive; Rec, receptive; Rimming, oral-anal behavior; $\beta_{2} \mathrm{M}, \beta_{2}$-microglobulin.

ing syphilis or gonorrhea during the 6 months prior to the 6 months pre-AIDS and reported number of sexual partners.

Given that $\mathrm{CD}^{+}{ }^{+}$cell levels were higher in AIDS-KS cases, we plotted the levels of CD4 cell number against the values of IL-6 for the whole study group and for cases and controls separately. The scatterplot suggested that higher levels of serum IL-6 were associated with lower levels of CD4 T cell numbers (Fig. 1). The regression line suggeted an inverse linear relationship between IL- 6 and CD4 cell number among cases and controls (Figs. 2 and 3 ). The estimated regression coefficient was as follows: $\beta=-0.0037$ with a $p$ value of 0.08 that tested the hypothesis of independence between IL- 6 and CD4. How- 


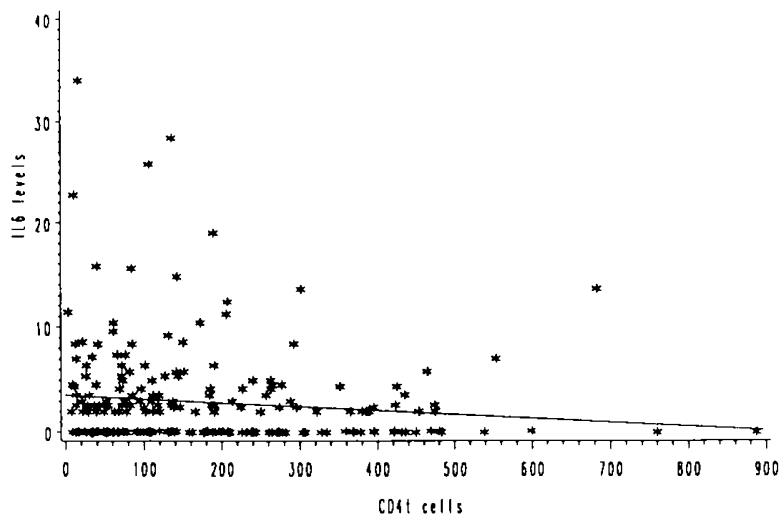

FIG. 1. Scatterplot of serum IL-6 and CD4 T cell number at 6 months prior to AIDS.

ever, the inverse linear relationship of IL-6 and CD4 seems to hold only among the controls. The correlation coefficient among controls was: $(r=-0.15, p=0.04)$ and among cases: $(r=0.032 ; p=0.80)$. We also plotted the values of serum $\beta_{2} \mathrm{M}$ and neopterin against the values of IL-6. $\beta_{2}$-Microglobulin and neopterin had a weak positive correlation with IL-6 among the cases $\left(\beta_{2} \mathrm{M}: r=0.12, p=0.45\right.$; neopterin: $\left.r=0.17, p=0.24\right)$, but neither was statistically significant. Among the controls, however, $\beta_{2} \mathrm{M}$ and neopterin were both positively significantly correlated with IL-6 $\left(\beta_{2} \mathrm{M}, r=0.26 ; p=0.01\right.$; neopterin, $r=$ $0.50 ; p=0.0001)$.

Table 4 shows logistic regression models for the IL-6-AIDSKS association. The IL- 6 odds ratios are the same for models 1 and 2 but changed slightly in models 3 and 4 . The inclusion of biological variables such as CD4 cell number, $\beta_{2} \mathrm{M}$, and neopterin decreases the magnitude of the IL- 6 association such that the odds ratios are no longer statistically significant. Oral-genital insertive intercourse, anal sex insertive and receptive, $\beta_{2} \mathrm{M}$, and neopterin are not significantly associated with case/control status. On the other hand, oral-genital receptive intercourse and CD4 cell number are significantly associated with AIDS-KS in models 1 and 2 and at borderline statistical significance in models 3 and 4 .

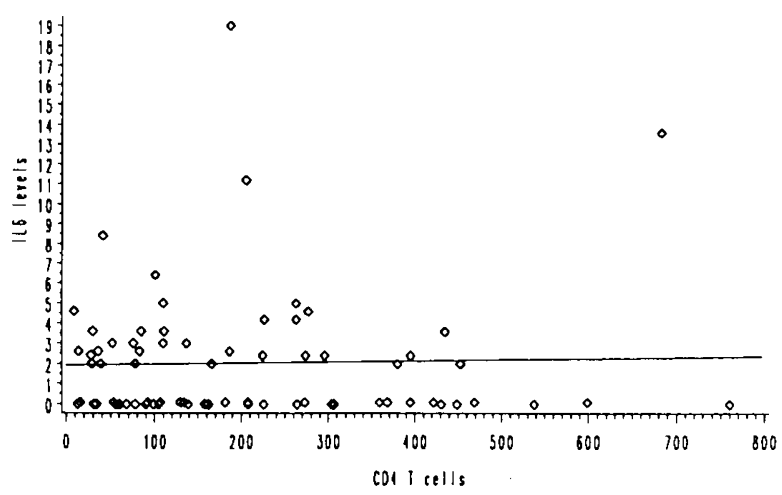

FIG. 2. Scatterplot of serum IL-6 and CD4 T cell number at 6 months prior to AIDS, among cases (AIDS-KS); $r=0.032$; $p=0.80$.

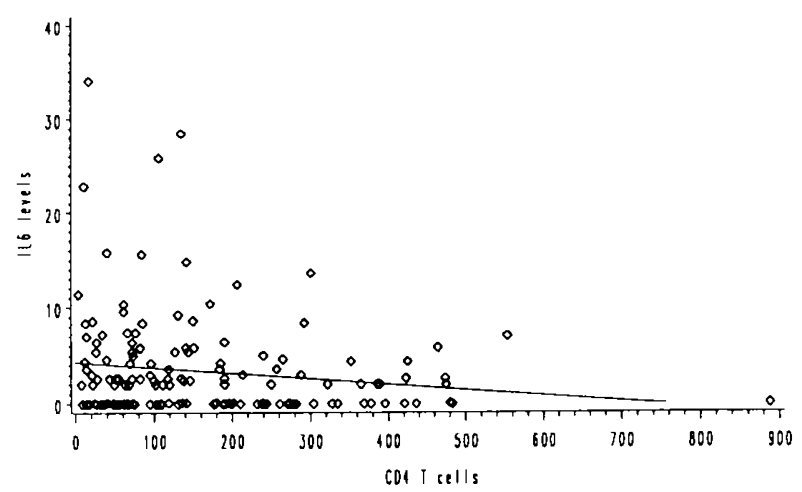

FIG. 3. Scatterplot of serum IL-6 and CD4 T cell number at 6 months prior to AIDS among controls (AIDS-OI); $r=0.15$, $p=0.04$.

Because of the limited sample size, to evaluate effect modification we fit the data to a logistic regression model that incorporated the preceding variables as product terms with the exposure variable in the model. The coefficients for these product terms did not have a value statistically significant from zero.

\section{DISCUSSION}

The results presented here confirm other findings that HIVinfected individuals have elevated serum concentrations of IL6. ${ }^{41,42}$ However, consistently elevated levels of serum IL-6 were seen only at 6 months pre-AIDS. Possible explanations for these findings are that there is no elevation in serum IL- 6 at 1 or 2 years prior to AIDS or, alternatively, that there was measurement error in testing for IL-6. It is possible that some or all of the samples from the MACS repository have undergone freeze/thaw procedures before they were examined in this study. However, it is not likely that this affected the IL-6 levels detected in this study: serum samples from the MACS, known to have high levels of IL-6, and frozen and thawed many times, did not show a significant loss in IL-6 levels detected with the same ELISA that was used in this study (data not shown). This suggests that the negative results seen at 2 years and 1 year prior to AIDS were in fact true negatives.

When AIDS-KS patients were compared to AIDS-OI patients, fewer AIDS-KS patients had detectable levels of serum IL- 6 at 6 months prior to AIDS. A hypothesis that could explain this inverse association is that the control group had more advanced HIV disease than the KS group. Evidence to support this hypothesis is that the cases had, on average, a higher CD4 $\mathrm{T}$ cell level than the controls. Individuals who have more advanced HIV infection probably have greater immune dysfunction. Therefore, elevated levels of IL-6 may represent greater immune dysfunction among HIV-infected individuals. In fact, results presented here indicate an association between low levels of CD4 T cells and higher serum IL-6 levels. Furthermore, our results suggest a potential association between markers of immune activation (neopterin, $\beta_{2} \mathrm{M}$ ) and IL-6 among controls. Another study ${ }^{43}$ that has investigated the association of IL-6 and CD4 did not find a correlation between these two markers. 
TABle 4. Logistic Regression Models of IL-6-AIDS-KS Association

\begin{tabular}{|c|c|c|c|c|c|c|c|c|}
\hline \multirow[b]{2}{*}{ Adjusting for: } & \multicolumn{2}{|c|}{ Model 1} & \multicolumn{2}{|c|}{ Model 2} & \multicolumn{2}{|c|}{ Model 3} & \multicolumn{2}{|c|}{ Model 4} \\
\hline & $O R^{\mathrm{a}}$ & $95 \% C I^{\mathrm{a}}$ & $O R$ & $95 \% C l$ & $O R$ & $95 \% C I$ & $O R$ & $95 \% C I$ \\
\hline IL-6 & 0.4 & $0.1-0.9$ & 0.4 & $0.1-1.1$ & 0.5 & $0.1-2.3$ & 0.5 & $0.1-2.5$ \\
\hline Oral-genital Ins ${ }^{\mathrm{b}}$ & 0.4 & $0.1-1.1$ & 0.3 & $0.0-1.0$ & 0.4 & $0.0-2.0$ & 0.4 & $0.0-2.0$ \\
\hline Oral-genital $\mathrm{Rec}^{\mathrm{b}}$ & 3.1 & $1.0-9.7$ & 3.3 & $1.1-10.7$ & 3.5 & $0.7-17.8$ & 3.4 & $0.6-18.1$ \\
\hline Anal sex Ins ${ }^{b}$ & 1.0 & $0.4-2.2$ & 1.1 & $0.5-2.5$ & 1.0 & $0.3-3.0$ & 1.0 & $0.3-3.0$ \\
\hline Anal sex $\operatorname{Rec}^{b}$ & 0.8 & $0.3-1.7$ & 0.7 & $0.3-1.6$ & 0.5 & $0.2-1.6$ & 0.5 & $0.1-1.6$ \\
\hline CD4 & & & 2.0 & $1.0-4.1$ & 2.2 & $0.8-5.8$ & 2.6 & $0.8-5.9$ \\
\hline$\beta_{2}$-Microglobulin & & & & & 0.5 & $0.2-1.5$ & 0.6 & $0.1-1.6$ \\
\hline Neopterin & & & & & & & 0.9 & $0.3-2.7$ \\
\hline
\end{tabular}

${ }^{\mathrm{a}} \mathrm{OR}$, Odds ratio; $\mathrm{CI}$, confidence interval.

'Ins, insertive; Rec, receptive.

However, their study group incorporated HIV-infected individuals with no signs of clinical disease. Furthermore, the serum IL- 6 concentrations were reported to be similar for healthy HIV antibody positives and HIV antibody negatives. These results support the hypothesis that IL- 6 may be a marker of relatively advanced disease and of immune dysfunction among HIV-infected individuals.

Even though an inverse association was found between serum IL-6 and AIDS-KS at 6 months prior to AIDS, it is still possible that IL- 6 exerts a growth effect on pre-KS cells. Interleukin 6 may be overproduced chronically and consumed at the nascent $\mathrm{KS}$ lesion sites, with the emerging $\mathrm{KS}$ cells binding available IL-6. In such a scenario, IL-6 would not appear in increased levels in the circulation.

An alternative explanation for these findings can be drawn from the fact that infections included in an AIDS diagnosis have an incubation period that can be several weeks to months in length. It is, therefore, likely that the individuals in the control group were already infected for up to 6 months before they were diagnosed with an AIDS-OI. The infection process may stimulate the production of IL-6. The preceding explanation could certainly hold for some or most of the diseases in our control group. For instance, in those with CMV retinitis, it is likely that there was shedding of CMV as long as 6 months before the development of retinitis. Mycobacterium infections are usually chronic infections with longer incubation periods. The incubation period for cryptoccocal meningitis is not known but a person can have the infection for months before a brain infection is manifested. Pneumocystis carinii pneumonia, Mycobacterium avium, cryptosporidiosis, and Candida esophagitis are diseases associated with immunodeficiency in HIV/AIDS. The infection can be asymptomatic until the immunodeficiency becomes more serious. Therefore it is likely that subjects in the control group had active infections in the 6 months prior to diagnosis.

The production of IL- 6 in response to different infections may enhance HIV viral replication and contribute to the AIDS pathogenesis. Cytokines can induce HIV expression, converting latent or chronic infections to productive ones, and/or by contributing to the generation of activated $T$ cells, thereby facilitating infection with HIV and propagating the spread of the virus. ${ }^{44}$ In fact, IL- 6 has been seen to enhance HIV replication directly in infected monocytes. ${ }^{45}$ If IL-6 in HIV infection does enhance HIV replication, using IL-6 inhibitors in monocytes may reduce HIV viral replication and consequently improve survival among HIV-infected subjects.

New information has pointed to KSHV/HHV-8 as an infectious etiologic agent for AIDS-KS. ${ }^{12,16,17,46,47}$ While it is clear that KSHV is associated with the presence of KS, the biological mechanism(s) by which this herpesvirus contributes to the pathogenesis of AIDS-KS have not been defined. It is possible that KSHV infection can induce cytokine production, thereby enhancing autocrine/paracrine growth of KS cells. The observation $^{23,24}$ that KSHV encodes a viral homolog (vIL-6) of cellular IL-6 (cIL-6) is exciting, and suggests that vIL-6 may play some role in $\mathrm{KS}$ pathogenesis. While there is clear homology between vIL- 6 and cIL- 6 , there are significant differences in amino acid composition between these two versions of IL6 . $^{23,24}$ This suggests that vIL- 6 would not be detected by the IL-6 ELISA used in this study, which was optimized for the detection of cIL-6. Studies to confirm this, and to examine the biological properties of vIL-6, are underway.

\section{ACKNOWLEDGMENTS}

The authors gratefully acknowledge the participation of the people in the MACS cohort, Reba Knox's technical assistance with the IL-6 ELISA, the assistance of Yasushi Kasahara of Fujirebio, Inc., with the IL-6 ELISA utilized in this study, the provision of results on $\beta_{2} \mathrm{M}$ and neopterin by the laboratory of John Fahey, the information of KSHV provided by Julia Gage, information on KS cases in the UCLA-MACS provided by Max Hechter, and the data management assistance of Shelia Jin.

Supported by grants from the NIH (UCLA Center of the Multicenter AIDS Cohort Study-AI35040, UCLA/Fogarty International Program in AIDS Epidemiology-TW00013 and CA01588), and the University of California AIDS Research Program (UCARP R91LA149).

\section{REFERENCES}

1. Friedman-Kien AE, Laubenstein LJ, Rubinstein P, BuimoviciKlein E, Marmor M, Stahl R, Spigland I, Kim KS, and Zolla-Pas- 
ner S: Disseminated Kaposi's sarcoma in homosexual men. Ann Intern Med 1982;96:639-699.

2. Cerimele D: Kaposi Sarcoma. Medical and Scientific Books Spectrum Publications, New York, 1985.

3. Center for Disease Control Task Force on Kaposi's Sarcoma and Opportunistic Infections: Epidemiologic aspects of the current outbreak of Kaposi's sarcoma and opportunistic infections. N Engl J Med 1982;306:248-252.

4. Ziegler JL, Templeton AC, and Vogel CL: Kaposi's sarcoma: A comparison of classical, endemic and epidemic forms. Semin Oncol 1984;11:47-52.

5. Friedman-Kien $\mathrm{AE}$ and Laubenstein $\mathrm{LJ}$ (eds.): AIDS: The Epidemic of Kaposi's Sarcoma and Opportunistic Infections. Masson Publishing, New York, 1984.

6. Safai B, Johnson KG, Myskowski PL, Koziner B, Yang SY, Cunningham-Rundles S, Godbold JH, and Dupont B: The natural history of Kaposi's sarcoma in the acquired immunodeficiency syndrome. Ann Intern Med 1985;103:744-750.

7. Ensoli B, Barillari G, and Gallo R: Pathogenesis of AIDS-associated Kaposi's sarcoma. Hematol Oncol Clin North Am 1991; 5:281-195.

8. Ensoli B, Buonaguro L, Barillari G, Fiorelli V, Gendelman R, Morgan RA, Wingfield P, and Gallo RC: Release, uptake, and effects of extracellular human immunodeficiency virus type 1 Tat protein on cell growth and viral transactivation. J Virol 1993;67:277-287.

9. Rosenberg ZF and Fauci AS: Immunopathogenic mechanisms of HIV infection: Cytokine induction of HIV expression. Immunol Today 1990;11:176-180.

10. Barillari G, Buonaguro L, Fiorelli V, Hoffman J, Michaels F, Gallo RC, and Ensoli B: Effects of cytokines from activated immune cells on vascular cell growth and HIV-1 gene expression. J Immunol 1992;149:3727-3734.

11. Barillari G, Gendelman R, Gallo RC, and Ensoli B: The Tat protein of human immunodeficiency virus type 1, a growth factor for AIDS Kaposi sarcoma and cytokine-activated vascular cells, induces adhesion of the same cell types by using integrin receptors recognizing the RGD amino acid sequence. Proc Natl Acad Sci USA 1993;90:7941-7945.

12. Beral V, Peterman TA, Berkelman RL, and Jaffe HW: Kaposi's sarcoma among persons with AIDS: A sexually transmitted infection? Lancet 1990;335:123-128.

13. Schechter MT, Marion S, Elmslie KD, Ricketts MN, Nault P, and Archibald CP: Geographic and birth cohort associations of Kaposi's sarcoma among homosexual men in Canada. Am J Epidemiol 1991;134:485-488.

14. Archibald CP, Schechter MT, Le TN, Craib KJ, Montaner JS, and O'Shaughnessy MV: Evidence for a sexually transmitted cofactor for AIDS-related Kaposi's sarcoma in a cohort of homosexual men. Epidemiology 1992;3:203-209.

15. Wahman A, Melnick SL, Rhame FS, and Potter JD: The epidemiology of classic, African and immunosuppressed Kaposi's sarcoma. Epidemiol Rev 1991;13:178-199.

16. Chang Y, Cesarman E, Pessin MS, Lee F, Culpepper J, Knowles DM, and Moore PS: Identification of herpesvirus-like DNA sequences in AIDS-associated Kaposi's sarcoma. Science 1994; 266:1865-1869.

17. Moore PS and Chang Y: Detection of herpes virus like DNA sequences in Kaposi's sarcoma in patients with and without HIV infection. N Engl J Med 1995;332:1181-1185.

18. Moore PS, Gao SJ, Dominguez G, Cesarman E, Lungu O, Knowles DM, Garber R, Pellett PE, McGeoch DJ, and Chang Y: Primary characterization of a herpesvirus agent associated with Kaposi's sarcoma. J Virol 1996;70:549-558.

19. Weiss RA: Perspectives on HHV8 and Kaposi's sarcoma. In: 3rd Conference on Retroviruses and Opportunistic Infections. Jan. 28-Feb. 1, 1996, Washington, D.C. p. 177
20. Li JJ, Huang YQ, Cockerell CJ, and Friedman-Kien A: Localization of human herpes-like virus type 8 in vascular endothelial cells and perivascular spindle-shaped cells of Kaposi's sarcoma lesions by in situ hybridization. Am J Pathol 1996;148:1741-1748.

21. Gao SJ, Kingsley L, Hoover DR, Spira TJ, Rinaldo CR, Saah A, Phair J, Detels R, Parry P, Chang Y, and Moore PS: Seroconversion to antibodies against Kaposi's sarcoma-associated herpesvirus-related latent nuclear antigens before the development of Kaposi's sarcoma. N Engl J Med 1996;335:233-241.

22. Cesarman E, Moore PS, Rao PH, Inghirami G, Knowles DM, and Chang Y: In vitro establishment and characterization of two acquired immunodeficiency syndrome-related lymphoma cell lines (BC-1 and BC-2) containing Kaposi's sarcoma-associated herpesvirus-like (KSHV) DNA sequences. Blood 1995;86:2708-2714.

23. Niepel F, Albrecht J-C, Ensser A, Huang J-Q, Li JJ, FriedmanKien A, and Fleckenstein B: HHV-8 encodes a homologue of IL6. J Virol 1996;71:839-842.

24. Moore PS, Boshoff C, Weiss RA, and Chang Y: Molecular mimicry of human cytokine and cytokine response pathway genes by KSHV. Science 1996;274:1739-1742.

25. Nakamura S, Salahuddin SZ, Biberfeld P, Ensoli B, Markhaw PD, Wong-Staal F, and Gallo RC: Kaposi's sarcoma cells: Long-term culture with growth factor from retrovirus-infected CD4 ${ }^{+} \mathrm{T}$ cells. Science 1988;242:426-430.

26. Corbeil J, Evans LA, Vasak, Cooper DA, and Penny R: Culture and properties of cells derived from Kaposi sarcoma. J Immunol 1991;146:2972-2976.

27. Miles SA, Rezai AR, Salazar-Gonzalez JF, Vander Meyden M, Stevens RH, Logan DM, Mitsuyasu RT, Taga T, Hirano T, Kishimoto T, and Martínez-Maza O: AIDS Kaposi's sarcoma-derived cells produce and respond to interleukin-6. Proc Natl Acad Sci USA 1990;87:4068-4072.

28. Martínez-Maza O, Rezai AR, Magpantay L, Klashman DJ, Johnson MT, Watson JM, Hirano T, Kishimoto T, and Miles SA: Interleukin 6: Role in AIDS-associated Kaposi's sarcoma. In: $I L-6$ : Physiopathology and Clinical Potentials (Revel M, ed.). Raven Press, New York, 1992, pp. 125-131.

29. Nair BC, DeVico AL, Nakamura S, Copeland TD, Chen Y, Patel A, O'Neil T, Oroszlan S, Gallo RC, and Sarngadharan MG: Identification of a major growth factor for AIDS-Kaposi's sarcoma cells as oncostatin M. Science 1992;225:1430-1432.

30. Miles SA, Martínez-Maza O, Rezai A, Magpantay L, Kishimoto T, Radka SF, and Linsley P: Oncostatin $M$ as a potent mitogen for AIDS-Kaposi's sarcoma-derived cells. Science 1992;255:14321434.

31. Palka J: Kaposi's sarcoma gives on key fronts. Science 1992; 255:1432-1434.

32. Masood R, Lunardi-Iskandar Y, Jean LF, Murphy JR, Waters C, Gallo RC, and Gill P: Inhibition of AIDS-associated Kaposi's sarcoma cell growth by DAB389-interleukin 6. AIDS Res Hum Retroviruses 1994;10:969-975.

33. Yang J, Hagan MK, and Offermann MK: Induction of IL-6 gene expression in Kaposi's sarcoma cells. J Immunol 1994;152: 943-955.

34. Bailer RT, Lazo A, Ng-Bautista CL, Hout BL, Ness GM, Hegtvedt AK, Blakeslee JR, Stephens RE, Brierley GP, and Mallery SR: Comparison of constitutive cytokine release in high and low histologic grade AIDS-related Kaposi's sarcoma cell strains and in sera from HIV +/KS + and HIV +/KS - patients. J Interferon Cytokine Res 1995;15:473-483.

35. Centers for Disease Control: Revision of the CDC surveillance case definition for AIDS. MMWR 1987;36(Suppl. 1S):3S-14S.

36. Kaslow RA, Ostrow DG, Detels R, Phair JP, Polk BF, and Rinaldo CR Jr: The multicenter AIDS cohort study: Rationale, organization and selected characteristics of the participants. Am J Epidemiol 1987;126:310-318. 
37. Detels R, Phair JP, Saah AJ, Rinaldo CR, Muñoz A, Kaslow RA, Seminara D, Schrager L, and Vermund S: Recent scientific contributions to understanding HIV/AIDS from the Multicenter AIDS Cohort Study. J Epidemiol (Japan) 1992;2(2):S11-S19.

38. Fleiss JL: Statistical Methods for Rates and Proportions. John Wiley \& Sons, New York, 1981.

39. Schlesselman JJ: Case-Control Studies: Design, Conduct, Analysis. Oxford University Press, New York, 1982.

40. SAS Institute Inc.: SAS Proprietary Software Release 6.07. Licensed to the University of California. SAS, Cary, North Carolina, 1989.

41. Breen EC, Rezai AR, Nakajima K, Beall GN, Mitsuyasu RT, Hirano $T$, Kishimoto $T$, and Martínez-Maza O: Infection with HIV is associated with elevated IL-6 levels and production. J Immunol 1990;144:480-484.

42. Birx DL, Redfield RR, Tencer K, Fowler A, Burke DS, and Tosato G: Induction of interleukin 6 during human immunodeficiency virus infection. Blood 1990;76:2303-2310.

43. Madhok R, Cruickshank A, Gracie AJ, Shenkin A, and Lowe GD: Increased interleukin 6 concentrations in the absence and presence of HIV infection in hemophilia. J Clin Pathol 1992;45:766-769.

44. Farrar WL, Korner M, and Clouse K: Cytokine regulation of human immunodeficiency virus expression. Cytokine 1991;6:531-542.

45. Poli G, Bressler P, Kinter A, Duh E, Timmer WC, Rabson A, Justement JS, Stanley S, and Fauci AS: Interleukin 6 induces human immunodeficiency virus expression in infected monocytic cells alone and in synergy with tumor necrosis factor alpha by transcriptional and post-transcriptional mechanisms. J Exp Med 1990;172:151158.

46. Beral V, Bull D, Darby S, Weller I, Carne C, Beecham M, and Jaffe H: Risk of Kaposi's sarcoma and sexual practices associated with faecal contact in homosexual or bisexual men with AIDS. Lancet 1992;339:632-635.

47. Abrams DI: The relationship between Kaposi's sarcoma and intestinal parasites among homosexual males in the United States. J Acquir Immune Defic Syndr 1990;3(Suppl. 1):S44S46.

Address reprint requests to: Inês Dourado

Instituto de Saúde Coletiva

Universidade Federal de Bahia Rua Padre Feijó $29-4^{\circ}$ andar-Canela Salvador, Bahia, Brazil-40.110.170 